\title{
THE UNIFORM COMPUTER INFORMATION TRANSACTIONS ACT
}

\author{
By Pratik A. Shab
}

The U.S. economy has evolved from a tangible goods-based economy in the 1950s, when the Uniform Commercial Code ("UCC") was initially adopted, to a service-based economy in which intangible information products and services play an increasingly important role. ${ }^{1}$ The underlying property law and ease of copying have caused sharp differences in contracting practices for computer information in comparison to traditional goods. ${ }^{2}$ Since the UCC was not designed to address licensing of such intangible goods or service contracts, the most significant transactions in the information age are currently subject to a "complex, conflicting and uncertain body of case and statutory law." 3 To clarify this murky area of law and provide a standard set of rules to efficiently regulate transactions in the new information industry, the National Conference of Commissioners on Uniform State Laws ("NCCUSL") promulgated the Uniform Computer Information Transaction Act ("UCITA"). ${ }^{4}$

UCITA, a model contract law statute, applies to "computer information transactions," including commercial agreements regarding use of computer software, computer databases, and Internet and online informa-

두 2000 Berkeley Technology Law Journal; Berkeley Center for Law \& Technology.

1. See Carol A. Kunze, The 2BGuide (visited Aug. 29, 1999) (http://www.2Bguide.com/handout.html); UNIF. COMPUTER INFO. TRANSACTIONS ACT, Prefatory Note (July 1999 Draft) [hereinafter UCITA]. All drafts of UCITA are available from the Uniform Law Commissioner's official draft site at 〈http://www.law.upenn.edu/ library/ulc/ulc.htm\#ucita).

2. See UCITA, Prefatory Note (July 1999 Draft). For example, when goods are sold, the buyer owns an exclusive right in the item purchased. In contrast, in a computer information transaction, the buyer may own the diskette but usually not the underlying informational rights. Furthermore, the technology involved makes computer information more susceptible to copying and alteration than print media does. See id.

3. Id. Choices of applicable law include a mix of federal and state intellectual property laws, consumer protection laws, and existing UCC Article 2 provisions. The paradigmatic example of the unique nature of computer information transactions and confusion in applying existing law are shrinkwrap licenses for software, which are discussed infra Part I.D.

4. See Ed Foster, What is UCITA? (last modified Aug. 30, 1999) 〈http://www.infoworld.com/cgi-bin/displayStory.pl?/features/99053lucital.htm); see generally UCITA, Prefatory Note (July 1999 Draft).

5. UCITA $\S 102(a)(11)$ (Oct. 15, 1999 Draft). 
tion. ${ }^{6}$ The stated purposes of UCITA are to "support and facilitate the realization of the full potential of computer information transactions in cyberspace; clarify the law governing computer information transactions; enable expanding commercial practice in computer information transactions by commercial usage and agreement of the parties; and make the law uniform among the various jurisdictions."7

This Note will provide a brief overview of UCITA's content, discussing its scope, mode of assent in contract formation, and mass market license regulations. The Note will explain how these provisions can potentially lead to consumer protection problems, focusing on UCITA's "optclauses" and its warranty coverage. The analysis then shifts to the question of federal preemption by examining the interaction between state contract law as proposed in UCITA and federal intellectual property laws. The Note concludes by arguing that the uncertainty resulting from these issues, as well as procedural variations introduced by individual states and their courts, may inhibit UCITA's overall goal of uniformity.

\section{UCITA: THE PROPOSED STATUTE}

\section{A. The Drafting Process}

Entirely independent of the federal government, uniform acts are adopted by the states individually after they are drafted and approved by the NCCUSL, a body of over 300 commissioners appointed by their respective states. ${ }^{8}$ The proposed acts are drafted in committee meetings open to all but usually attended only by attorneys representing the interested groups. ${ }^{9}$ UCITA evolved from such a project begun over a decade ago. From 1995 until the spring of 1999, UCITA was known as UCC Article $2 \mathrm{~B}$, as it was being drafted to be part of the UCC. ${ }^{10}$ UCC articles are drafted and approved by the NCCUSL in conjunction with the American

6. See UCITA, Prefatory Note (July 1999 draft).

7. Id.

8. See Foster, supra note 4; see also Kunze, supra note 1.

9. See Foster, supra note 4. One recurring criticism of Article 2B, the precursor to UCITA, is that large industry groups such as software companies dominated its drafting process. Curiously, just days after NCCUSL approved UCITA, Professor Raymond Nimmer, Reporter for Article 2B/UCITA, testified as an expert witness on behalf of Microsoft in a tax case. See Ed Foster, UCITA Author Does Some Moonlighting for Money, Courtesy of Microsoft (Oct. 11, 1999) (http://www.infoworld.com/articles/op/xml/99/10/ 11/99101 lopfoster.xml).

10. See Foster, supra note 4. 
Law Institute ("ALI"). ${ }^{11}$ Article 2B evoked a great amount of comment and criticism from industry groups, ${ }^{12}$ academics, ${ }^{13}$ consumer advocates, ${ }^{14}$ governmental agencies, ${ }^{15}$ and others, ${ }^{16}$ and underwent several draft revi-

11. The Reporter for Article 2B was Professor Raymond Nimmer. The Drafting Committee consisted of NCCUSL Commissioners and three ALI representatives. In addition, there were four advisors from the American Bar Association. Generally, about 50 to 80 observers also attended the meetings. Everyone was permitted to participate in the discussions, but only Committee members had voting privileges to amend the drafts. See The 2BGuide, Report on the November 13-15, 1998 Drafting Committee Meeting (visited Oct. 2, 1999) 〈http://www.2bguide.com/nov98rpt.html〉 [hereinafter November Meeting Report].

12. Those in the industry who objected include the Motion Picture Association of America Inc., Recording Industry Association of America Inc., Newspaper Association of America, National Association of Broadcasters, National Cable Television Association, and Magazine Publishers of America. See Letter from Jack Valenti, Motion Picture Association of America, et al., to John McClaugherty, President-Elect, NCCUSL (May 10, 1999), available at 〈http://www.2bguide.com/docs/coalit5.html〉 (critiquing overly broad scope of UCITA and its "one-size-fits all" approach to information transactions as potentially disrupting the well-established business practices of traditional media industries).

13. See generally Symposium, Intellectual Property and Contact Law in the Information Age: The Impact of Article 2B of the Uniform Commercial Code on the Future of Transactions in Information and Electronic Commerce, 13 BERKELEY TECH. L.J. 809 (1998); Symposium, Intellectual Property and Contract Law for the Information Age: The Impact of Article $2 B$ of the Uniform Commercial Code on the Future of Information Commerce, 87 CALIF. L. REV. 1 (1999).

14. Examples include the Consumers Union, Consumer Project on Technology, and Ralph Nader. See, e.g., Letter from Gail Hillebrand, Consumers Union, to Uniform Law Commissioner (June 21, 1999), available at (http://www.2bguide.com/docs/cu699.html); Letter from Ralph Nader to Uniform Law Commissioners (July 18, 1997), available at 〈http://www.cptech.org/ucc/nader2.html). For a discussion of the prevalent consumer concerns regarding UCITA, see infra Part II.

15. Government critics include 24 state attorneys general and the FTC. See Letter from State Attorneys General to Gene Lebrun, President, NCCUSL (July 23, 1999), available at (http://www.2Bguide.com/docs/799ags.html/ [hereinafter State Attorneys General Letter]; Letter from State Attorneys General to Gene Lebrun, NCCUSL (July 28, 1999), available at /http://www.2Bguide.com/docs/799mags.html;; Letter from Staff of the FTC to John L. McClaugherty, Chairman, Executive Committee, NCCUSL (July 9, 1999) available at 〈http://www.ftc.gov/be/v990010.htm〉. For a discussion of their consumer-focused criticisms, see infra notes 57-60.

16. Among the diverse body of other parties criticizing Article 2B were library associations, see Letter from Library Associations to Gene N. Lebrun, President NCCUSL (July 12, 1999), available at 〈http://www.arl.org/info/letters/lebrun7.12.html) (expressing the threat Article 2B posed to the maintenance of a rich public domain); various bar association committees, see, e.g., Committee on Copyright and Literary Property of the Association of the Bar of the City of New York, Report on a Proposal of the National Conference of Commissioners on Uniform State Laws to Adopt a Proposed Uniform Computer Information Transactions Act (June 21, 1999), available at (http://www.2Bguide.com/ 
sions. Many in the ALI were also critical of Article 2B, and in April 1999, the ALI withdrew its support of the legislation. ${ }^{17}$ As a result, the project's status shifted from a UCC article to a freestanding uniform act called UCITA. ${ }^{18}$ Since endorsement of uniform acts outside of the UCC depends solely on the NCCUSL, this status change enabled the NCCUSL to vote on UCITA at its July 1999 meeting, ${ }^{19}$ where UCITA was approved by a 43-6 state count. ${ }^{20}$ Though no longer carrying the prestigious UCC label, UCITA will now appear before legislatures in all fifty states for possible enactment this year. ${ }^{2}$

\section{B. Scope}

Despite much grander ambitions in its earlier Article $2 \mathrm{~B}$ form, ${ }^{22}$ UCITA's current scope is limited to "computer information transactions." 23 UCITA defines "computer information transaction" as "an agreement ... to create, modify, transfer, or license computer information or information rights in computer information.... A transaction is not included merely because the parties' agreement includes that their communications about the transaction will be in the form of computer information." ${ }^{24}$ Covered contracts include those to license software, create a com-

docs/Copy.Comm1.pdf); and individual lawyers and law firms, see Letter from Hank Barry, Wilson Sonsini Goodrich \& Rosati, to Uniform Law Commissioners (July 8, 1999) available at 〈http://www.2bguide.com/docs/wsgr7899.pdf).

17. See ALI \& NCCUSL, NCCUSL to Promulgate Freestanding Uniform Computer Information Transactions Act - ALI and NCCUSL Announce that Legal Rules for Computer Information Will Not Be Part of UCC (Apr. 7, 1999) (joint press release), available at 〈http://www.2bguide.com/docs/040799pr.html〉.

18. See id.

19. See Foster, supra note 4.

20. See Carlyle C. Ring, Jr. \& Ray Nimmer, Series of Papers on UCITA Issues (last modified Aug. 26, 1999) available at (http://www.2bguide.com/docs/q\&apm.html).

21. See Foster, supra note 4. UCITA will also appear before the legislatures of the District of Columbia, Puerto Rico, and the U.S. Virgin Islands.

22. The original scope of the proposed uniform law was digital information. Later, "responding to obvious convergence in information industries and the increasing relevance of digital technology," the project expanded to cover all transactions involving information, electronic and non-electronic. U.C.C. Article 2B, Preface (Aug. 1, 1998 Draft), available at $\langle\mathrm{http} / / \mathrm{www}$.law.upenn.edu/bll/ulc/ucc2b/2b898.htm〉. However, objections by various media industries, see supra note 12, forced the Committee to scale back UCITA's reach to computer information transactions only, see November Meeting Report, supra note 11.

23. See UCITA $\S 103$ (July 1999 Draft).

24. Id. § 102(a)(12). "Computer information" means "information in electronic form that is obtained from or through the use of a computer, or that is in digital or similar form capable of being processed by a computer. The term includes a copy of information in 
puter program, distribute information on the Internet, and gain access to online databases. ${ }^{25}$ Specifically excluded are contracts over "audio or visual programming that is provided by broadcast, satellite, or cable," as well as "a motion picture, sound recording, musical work, or phonorecord." 26 UCITA does not cover these contracts even if made available over the Internet, ${ }^{27}$ but UCITA would apply to these industries to the extent they directly competed with online companies in interactive computer information. $^{28}$

If a contract involves both computer information and other subject matter, UCITA applies only to the part of the agreement that involves computer information, except when the computer information is the primary subject matter. ${ }^{29}$ UCITA does not apply to software embedded in goods other than a computer or computer peripheral unless the main purpose of the transaction is to obtain the software. ${ }^{30}$ For example, UCITA would not apply to the purchase of software embedded in a toaster. ${ }^{31}$

UCITA does permit parties to "opt-in" to its regime fully and thereby designate one set of rules to govern a mixed transaction, as long as the transaction materially involves computer information. ${ }^{32}$ Similarly, parties are allowed to opt-in to UCITA for transactions involving information in a medium otherwise excluded from UCITA. ${ }^{33}$ Thus, while UCITA's scope is limited at first inspection, it can potentially cover a much broader range of information-related transactions. This result is of special interest to traditional media industry groups, which otherwise appear to enjoy a blanket exception under section 103(d)(2). UCITA also permits parties to "opt-

that form and any documentation or packaging associated with the copy." Id. $\S$ 102(a)(10).

25. See Ring \& Nimmer, supra note 20 .

26. UCITA $\S 103(d)(2)$ (Oct. 15, 1999 Draft).

27. See Ring \& Nimmer, supra note 20.

28. See Carlyle C. Ring, Jr., Summary of Action at Article 2B Meeting November 13-15, 1998 (visited Feb. 9, 2000) ("If these [movies, sound recording, and broadcasting] industries compete directly in interactive computer information with software and on-line companies, only to that extent, would these industries be subject to the rules developed by Article 2B. Presently very few, if any, products of these industries are on-line with interactivity."), available at 〈http://www.2bguide.com/docs/cr1 198sum.html〉.

29. See UCITA \& 103(b) (Oct. 15, 1999 Draft). Whether computer information is the primary purpose of a transaction is determined by the "material purpose" test, which asks if computer information or other subject matter is the focus of the contract. If it is, then UCITA governs the whole transaction. See id. § 103, Official Comment 4(a).

30. See id. $\S 103(\mathrm{~b})(1)$.

31. See Ring \& Nimmer, supra note 20.

32. See UCITA $§ 104$ (Oct. 15, 1999 Draft).

33. See id. 
out" of UCITA's terms, pursuant to certain protective limits for massmarket transactions. ${ }^{34}$

\section{Assent and Contract Formation}

UCITA adopts the idea of "manifesting assent" described in the Restatement (Second) of Contracts ${ }^{35}$ and applies it to computer information transactions. ${ }^{36}$ Like the common law, UCITA construes any conduct as a binding manifestation of assent if the party had reason to know its acts would be treated as assent to the terms. ${ }^{37}$ UCITA, however, explicitly adds the requirements that the licensee have an "opportunity to review" the terms prior to assenting and also that she reaffirm assent for electronic transactions. ${ }^{38}$ A person has an "opportunity to review" a term only if the term is "made available in a manner that ought to call it to the attention of a reasonable person and permit review." 39 However, UCITA also recognizes an "opportunity to review" terms after a person becomes obligated to pay or begin performance under certain circumstances, ${ }^{40}$ even for massmarket licenses. ${ }^{41}$

\section{Mass-Market Licenses}

Mass-market transactions include all consumer contracts as well as transactions involving other end-users if the transaction is directed to the general public or conducted under terms consistent with an ordinary retail transaction. ${ }^{42}$ Under UCITA, mass-market licenses are typically enforceable only if the licensee manifests assent to the contract after having an opportunity to review its terms. ${ }^{43}$ Furthermore, mass-market license terms

34. See id. $\S 104(1),(2)(\mathrm{B}),(3)$. The "opt-out" provision for mass-market transactions is limited by consumer protection statutes, unconscionability, public policy, and good faith; it also requires "conspicuous" presentation of such a clause.

35. See RESTATEMENT (SECOND) OF CONTRACTS $§ 19$ (1981) ("(1) The manifestation of assent may be made wholly or partly by written or spoken words or by other acts or by failure to act. (2) The conduct of a party is not effective as a manifestation of his assent unless he ... has reason to know that the other party may infer from his conduct that he assents. (3) The conduct of a party may manifest assent even though he does not in fact assent. In such cases a resulting contract may be voidable because of fraud, duress, mistake, or other invalidating cause.").

36. See UCITA $\$ 112$ (Oct. 15, 1999 Draft).

37. See id. § 112(a)(2), (d).

38. See id. $\$ 112(\mathrm{a}),(\mathrm{d})$.

39. Id. $\$ 112(\mathrm{e})(1)$.

40. See id. $\$ 112(\mathrm{e})(3)$.

41. See id. $\S \S 209(\mathrm{~b}), 210(\mathrm{~b})$.

42. See id. $\$ 102(a)(44)$.

43. See id. § 209(b). 
are limited by unconscionability, fundamental public policy, and express agreements between the parties. ${ }^{44}$

Shrinkwrap licenses are a special form of mass-market license. They are not revealed until after an initial agreement to acquire a product; in other words, there is no opportunity to review terms before payment. ${ }^{45}$ One of the central issues prompting the drafting of UCITA was the enforceability of shrinkwrap software licenses under state law. ${ }^{46}$ UCITA validates shrinkwrap licenses if three criteria are met. First, the licensee must have reason to know that additional contract terms will be proposed after the initial agreement. ${ }^{47}$ Second, she must be given the right to return the product at the licensor's cost. Finally, the licensee must be compensated for reasonable costs of restoring the system if it is altered by the installation of license terms for review. ${ }^{48}$ The same standard of "manifesting assent" applies as for all other licenses under UCITA. ${ }^{49}$

\section{STATE CONTRACT LAW AND CONSUMER PROTECTION ISSUES}

\section{A. Problem of Assent}

Much of the debate on UCITA's substance at the state law level centers around its contract formation rules, especially in the context of massmarket transactions. Under UCITA's contract formation provisions, a party can manifest assent to a contract by acting or even by failing to act. ${ }^{50}$ The liberal construction of assent in UCITA undermines the fundamental contract law requirement of a "meeting of the minds" in contract forma-

44. See id. $\$ \$ 209$ (a), 105(b).

45. See Ring \& Nimmer, supra note 20; see also UCITA $\$ 209$, Official Comment 4 (Oct. 15, 1999 Draft).

46. See, e.g., Kunze, supra note 1. Case authority exists on both sides for the enforceability of shrinkwrap licenses under current state contract law (i.e. UCC Article 2), but the more recent cases have validated such licenses. In ProCD, Inc. v. Zeidenberg, 86 F.3d 1447, 1452-53 (7th Cir. 1996), the court held shrinkwrap terms for software purchased from a retail store to be enforceable. The court characterized the shrinkwrap license as an "offer" that the buyer "accepted" by using the software without objection after having an opportunity to review the terms. See also Hill v. Gateway 2000 Inc., 105 F.3d 1147 (7th Cir. 1997) (same); M.A. Mortenson Co. v. Timberline Software Co., 93 Wash. App. 819 (1999) (same). But see Step-Saver Data Sys., Inc. v. Wyse Technology, 939 F.2d 91, 103 (3d. Cir. 1991) (holding that shrinkwrap terms are merely proposals for amending a contract of sale and not part of the contract for sale).

47. See UCITA $\$ 208(2)$ (Oct. 15, 1999 Draft); id. § 209, Official Comment 2(a).

48. See id. \$209(b).

49. See id.

50. See id. § 112; Ring \& Nimmer, supra note 20. 
tion. ${ }^{51}$ Although the efficiency from this mode of assent might make it desirable under traditional contract law, inferring assent from a failure to act allows for consumer abuse in the context of mass-market computer information licenses. The potential danger to consumers becomes especially acute for shrinkwrap licenses, in which the terms are not presented until after payment or use has begun. For these contracts, a mere failure to return the product can constitute assent and thus bind consumers to unintended terms. Besides the extra hassle of returning products, the failure may stem from the licensee's belief that payment had completed the transaction rather than any intention to accept additional license restrictions. Allowing such an indirect and ambiguous mode of assent is difficult to justify under any circumstance. Given the greater ability for prepresentation and prereview of contract terms in an online setting, where much computer information licensing occurs, enforcing shrinkwrap license terms based on a failure to act becomes almost indefensible. ${ }^{52}$

Another example in which UCITA's notion of assent may lead to consumer problems is in UCITA's "opt clauses." 53 For mass-market transactions, any terms invoking the opt provisions must be "conspicuous" in order to have effect. ${ }^{54}$ While at first glance this seems to be a welcome requirement for consumers, a further investigation into UCITA's definition of "conspicuous," 55 which expressly preempts any state law definition of the term, ${ }^{56}$ reveals otherwise. UCITA's definition fails to adhere to two key principles underlying the Federal Trade Commission Act, the model

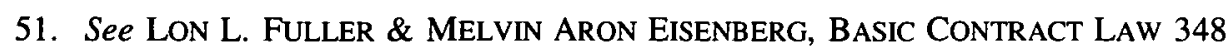
(6th ed. 1996) ("It is very commonly asserted that a contract requires 'a meeting of the minds."')

52. See Maureen A. O'Rourke, Progressing Towards a Uniform Commercial Code for Electronic Commerce or Racing Towards Nonuniformity?, 14 BERKELEY TECH. L.J. 635,652 (1999) (arguing that the technology of online transactions enables licensors to present all terms up front and assures that the consumer has clicked through such terms before assent is given).

53. "Opt clauses" refers to UCITA $\S 104$, allowing parties to "opt-in" or "opt-out" of UCITA as controlling law.

54. UCITA § 104(3) (Oct. 15, 1999 Draft).

55. Id. $\S 102(\mathrm{a})(14)$ ("Conspicuous,' with reference to a term, means so written, displayed, or presented that a reasonable person against which it is to operate ought to have noticed it. ... Conspicuous terms include the following: ... (i) a heading in capitals in a size equal to or greater than, or in contrasting type, font, or color to, the surrounding text; (ii) the language in the body of a record or display in larger or other contrasting type, font, or color or set off from the surrounding text by symbols or other marks that draw attention to the language; and (iii) a term prominently referenced in an electronic record or display which is readily accessible and reviewable from the record or display....").

56. See id. $\S 105(\mathrm{~d})(3)$. 
for most state consumer disclosure laws. ${ }^{57}$ First, the FTC model evaluates disclosures according to how likely they are to be communicated, not just "noticed." 58 Second, the FTC aims to ensure that disclosures are made in a timely manner; post-purchase disclosures do not conform to this requirement. ${ }^{59} \mathrm{By}$ providing a relaxed standard for meeting the threshold of "conspicuous" and permitting opt clauses in shrinkwrap licenses, UCITA's definition does not further either of these important consumer protection policies. UCITA's inclusion of various "safe harbors" in its definition of "conspicuous" exacerbates the problem. ${ }^{60}$ Given that the UCITA definition does not ensure effective communication of the opt clause, consumers may be conceding to such a term without meaningful assent.

Proponents of the opt clauses in UCITA, on the other hand, preach the "freedom of contract" philosophy. ${ }^{61}$ The advantage of giving contracting parties choice over governing rules rests on the assumption that parties will choose the system that minimizes transaction costs and increases the net benefit of the particular transaction. The savings in costs and uncertainty are especially evident for mixed transactions, where two different regimes of contract law might otherwise operate. ${ }^{62}$ However, given the bargaining power of most licensors over licensees in the mass-market shrinkwrap context, where adhesion contracts are the norm, this apparent efficiency could come at the licensee's expense. ${ }^{63}$ Some licensees may not

57. See State Attorneys General Letter, supra note 15; Staff of the FTC, supra note 15 , at n.6.

58. See State Attorneys General Letter, supra note 15.

59. See id.

60. See id.; see also Staff of the FTC, supra note 15, at n.6 ("UCITA's approach to 'conspicuous' disclosure fails to take into consideration the context in which the disclosure is given. For example, UCITA includes several broad safe harbors in its definition of 'conspicuous,' so that, for example, a disclosure which is 'in capitals in a size equal to or greater than, or in contrasting type, font, or color to, the surrounding text' (UCITA $\S$ 102(a)(14)(A)(i)) would be considered conspicuous regardless of the context of the disclosure. Thus, under UCITA a disclosure would be considered 'conspicuous' even if such a disclosure were buried amid boilerplate license text, or were printed on one of many different leaflets enclosed within a software box.").

61. See UCITA, Prefatory Note (July 1999 Draft) ("The first commercial law theme is that contract law should preserve freedom of contract.").

62. See Ring \& Nimmer, supra note 20 . The authors provide an example where a software company (governed by UCITA) and a cable company (governed by Article 2) wish to create a new business under a contract. The "opt" clauses would presumably reduce the uncertainty produced by the conflicting bodies of law.

63. See, e.g., State Attorneys General Letter, supra note 15 ("We are concerned that the policy choices embodied in these new rules [UCITA] almost invariably favor a relatively small umber of vendors to the detriment of millions of businesses and consumers who purchase computer software and subscribe to internet services."). 
even realize they are "assenting" to such terms, a danger amplified by UCITA's weak threshold of "conspicuousness." Contrary to the purpose of the opt clauses, these results imply an absence of a "freedom to contract." Related concerns about licensor manipulation of the applicable legal rules also arise in UCITA's choice of law and forum rules ${ }^{64}$ as well as modification of contract formation rules for future transactions between particular parties. ${ }^{65}$ In fact, the inadequacy of consumer consent in these provisions may be even more severe because they lack a "conspicuous" requirement to make the terms enforceable. ${ }^{66}$

\section{B. Warranty Concerns}

Consumer protection problems also arise in UCITA's warranty provisions. UCITA adopts several existing warranties from UCC Article $2^{67}$ and creates new warranties specific to computer information. ${ }^{68}$ However, subtle differences in the computer information context give rise to some concerns for licensees. First, UCITA permits licensors to disclaim the im-

64. See UCITA $\S \S 109,110$ (Oct. 15, 1999 Draft).

65. See id. $\S 112$ (f) ("The provision of this section may be modified by an agreement setting out standards applicable to future transactions between the parties."). Several state attorneys general have expressed their concern as to the potential manipulation of this provision by licensors: "The Attorneys General certainly understand the need for commercial buyers and sellers to be able to determine for themselves how they will conduct business over a course of dealing. However, extending the ability to change the basis rules of contract formation to merchants doing business with consumers via mass market contracts will open the door to consumer confusion and deception." State Attorneys General Letter, supra note 15.

66. See UCITA $\S \S 109,110,112$ (f) (Oct. 15, 1999 Draft) (lacking any "conspicuous" requirement).

67. See U.C.C. $\S \S 2-312$ (Warranty of Title and Against Infringement); 2-313 (Express Warranties by Affirmation); 2-314 (Implied Warranty: Merchantability); \& 2-315 (Implied Warranty: Fitness for a Particular Purpose). The analogous UCITA warranties are $\$ 401$ (creating warranty of noninfringement and substituting Article 2's warranty of title with warranty of quiet enjoyment); $\S 402$ (providing similar standard for creation of express warranties as Article 2 and explicitly adding advertising as basis for such warranty); $\S 403$ (creating implied warranty of merchantability for computer programs but specifically excluding informational content); $\S 405$ (providing similar implied warranty that product will meet reasonably known needs of licensee as in Article 2 but adding qualifications for published informational content).

68. See UCITA $\S 401$ (Oct. 15, 1999 Draft) (substituting warranty of quiet enjoyment for Article 2's warranty of title); id. $\S 404$ (creating new implied warranty for informational content accuracy if prepared in a "special relationship of reliance" with a licensee); id. $\S 405$ (c) (providing implied warranty of system integration if licensor has reason to know licensee is relying on its skill in selecting components of computer system). 
plied warranties as long as such a disclaimer is "conspicuous." cussed above for the opt clauses, UCITA's broad definition of "conspicuous" can hurt unsuspecting consumers who might not have given genuine consent to the disclaimer. ${ }^{70}$ Moreover, in nonautomated transactions, just an inconspicuous disclaimer is sufficient to nullify the warranties of quiet enjoyment and noninfringement. ${ }^{71}$ Thus, consumers will have less certainty in their rights to use licensed computer information, since, contrary to first appearance, such information is not necessarily guaranteed to be free from competing third-party claims of infringement or misappropriation.

The second consumer protection problem is that UCITA's implied warranty on accuracy of informational content does not cover "published informational content." "72 Examples of published informational content include the content of digital newsletters, multimedia encyclopedias, and on-line databases. Proponents of the limitation argue that this class of digital information deserves the same protection as its counterpart in the print media, which the courts shield from normal tort liability. ${ }^{73}$ Two

69. Id. $\S 406(\mathrm{~b})(1)(\mathrm{A})$. However, even this requirement can seemingly be circumvented. Section 406(c), which supercedes the conditions for disclaimer set forth in $\S$ 406(b), makes no mention of the "conspicuous" requirement and provides that licensors may simply use expressions like "as is" or "with all faults" to disclaim all implied warranties. Id. § 406(b), (c). Furthermore, the statute allows for disclaimer of implied warranties by "usage of trade." Id. $\S 406(\mathrm{e})$. Although this clause may have been appropriate for well-established industries governed by Article 2, it is premature for information transactions in which customs are still developing. UCITA would better serve licensors and licensees by guiding these customs in the direction of desirable practices. See O'Rourke, supra note 52, at 651.

70. See supra notes 53-60.

71. See UCITA \& 401(d) (Oct. 15, 1999 Draft) ("[For non-automated transactions,] language in a record is sufficient if it states 'There is no warranty against interference with your enjoyment of the information or against infringement', or words of similar import.").

72. See id. $\S 404(\mathrm{~b})(1)$. UCITA defines "published informational content" as "informational content prepared for or made available to recipients generally, or to a class of recipients, in substantially the same form," as opposed to a personally-tailored service. Id. $\S 102(a)(51)$.

Section 404(a) does offer a warranty against inaccuracies for informational content provided in a "special relationship of reliance" with the licensee if the inaccuracies are caused by the merchant's failure to use reasonable care. Id. $\$$ 404(a). This parallels how the Restatement (Second) of Torts $\$ 552$ treats information providers under tort law. See id. $\S 404$, Official Comment 3(a) (citing Murphy v. Kuhn, 90 N.Y.2d 266, 682 N.E.2d 972 (N.Y. 1997)).

73. See UCITA § 404, Official Comment 3(b) (Oct. 15, 1999 Draft); Ring \& Nimmer, supra note 20 (citing Cubby, Inc. v. CompuServe, Inc., $3 \mathrm{CCH}$ Computer Cases 46, 
strong policy justifications bolster their position. First, the risk of excessive liability could stifle the beneficial proliferation of mass digital information in cyberspace. ${ }^{74}$ Second, UCITA's exemption for published informational content advances First Amendment values within contract law by encouraging the distribution of such information. ${ }^{75}$

However, these arguments fail to acknowledge the potentially overbroad scope of the exception. The digital medium includes more than just traditional newspaper or phonebook content. For example, user interfaces and source code in software products differ significantly from traditional databases, but may still qualify as published informational content under UCITA. ${ }^{76}$ Therefore, the exception has the potential to creep into massmarketed software and prevent consumer recovery for product defects under UCITA's implied warranties. ${ }^{77}$ Moreover, not all published informational content is exempt from liability in traditional print media. Producers of navigational charts, for instance, have been held liable for the impact of inaccuracies on users. ${ }^{78}$ Since the UCITA provision does not distinguish between published information that is exempt and nonexempt in the digital realm, it could provide broader immunity to sellers of this information than is available in nondigital forms, allowing them to act with less care in preparing digital information. ${ }^{79}$

47 (S.D.N.Y. 1999) for their proposition that "[c]ourts have recognized that digital information deserves protection just like traditional newspapers and magazines").

74. See Ring \& Nimmer, supra note 20.

75. See id.

76. See Letter from Barbara Simons, Association for Computing Machinery, to Uniform Law Commissioner (July 12, 1999) available at 〈http://www.acm.org/usacm/ copyright/usacm-ucita.html (arguing that designing user interfaces is part of the engineering process and that user interface errors are part of the computer program; thus, such errors should not be classified as equivalent to errors in the content of a newspaper article); see also Michele C. Kane, When Is a Computer Program Not a Computer Program? The Perplexing World Created by Proposed UCC Article 2B, 13 BERKELEY TECH. L.J. $1013,1016-18$ (1998) (arguing that other previously protected items such as source code and "off-the-shelf" software may fall victim to the warranty exception for published information).

77. See Kane, supra note 76, at 1017-19. But see UCITA § 404, Reporter's Note 6 (July 1999 draft) (claiming that UCITA neither precludes nor encourages further development of liability issues under tort law).

78. See Aetna Cas. \& Sur. Co. v. Jeppesen \& Co., 642 F.2d 339, 341-43 (1981) (holding producer of defective aeronautical chart liable for chart's role in causing airplane crash).

79. UCITA also generates other consumer protection concerns, in such areas as its electronic commerce/digital signature rules and electronic self-help provision, that also merit consideration but are beyond the scope of this paper. For a description of consumer concerns relating to digital signatures, authentication procedures, and electronic con- 


\section{INTERACTION WITH FEDERAL INTELLECTUAL PROPERTY LAWS}

Given the nature of information licensing, a complete analysis of UCITA requires an investigation into the interaction between state contract law and federal intellectual property law. ${ }^{80}$ For example, contracts that impose limitations on copying or distribution of information implicate values embodied in federal copyright law. The major issue facing UCITA is whether federal copyright law does (or should) preempt private information contracts governed by UCITA. While the "symbiotic" view treats federal intellectual property laws as background rules subject to alteration by contract, the preemptive view suggests that the Supremacy Clause does not permit contract provisions to trump congressional mandates. Federal

tracting under UCITA, see generally Michael Froomkin, Article 2B as Legal Software for Electronic Contracting-Operating System or Trojan Horse?, 13 BERKELEY TECH. L.J. 1023 (1998). Froomkin asserts that "Article 2B [now UCITA] undermines the consumer law requirements it seeks to modernize and risks leaving consumers particularly vulnerable to more modern threats caused by hacked software and rogue electronic agents." Id. at 1048 . He specifically points to a lack of appropriate standards to judge UCITA's contracting requirements such as the use of "reasonably configured" electronic agents. See id. at 1049-51. For a comparison of UCITA and the Uniform Electronic Transactions Act (UETA), and their relative merits, see Cem Kaner, E-Commerce Provisions in the UCITA and UETA (visited Sept. 6, 1999) (http://www.badsoftware.com/uetaanducitauccbull.htm〉 (arguing that UCITA, unlike UETA, creates several consumer dangers such as a presumption for authentication, greater consumer liability for fraudulent signatures, lack of requirement to make available downloaded contract, and mass-market choice of law and forum provisions).

For a commentary on how software vendors can abuse UCITA's self-help provisions, see Ed Foster, Beware of Licensing Terms Giving Vendors the Right to Detonate Software Bombs (visited Sept. 6, 1999) (http://www.infoworld.com/cgi-bin/ displayNew.pl?/foster/990830ef.htm $\rangle$. For a different perspective, see Sharon Marsh Roberts \& Cem Kaner, Self-help Under UCITA (July 23, 1999) 〈http://www.badsoftware.com/shelp.htm). These critics of UCITA argue that while the UCITA self-help provision was a good effort at compromise, it still suffers from three serious problems: (1) for vendors who legitimately need help, UCITA's 15-day delay is too long; (2) for customers, the "backdoor" access into their system poses a security risk; and (3) for small software licensors, the rules are too technical, preventing the licensors from appropriate use of self-help remedy even for good-faith attempts. See id. These authors also reject as inapposite comparisons of UCITA to UCC Article 9, since "selfhelp in the computer case does so much collateral damage." Id

80. See generally Symposium, Intellectual Property and Contract Law in the Information Age: The Impact of Article $2 B$ of the Uniform Commercial Code on the Future of Transactions in Information and Electronic Commerce, 13 BERKELEY TECH. L.J. 809 (1998); Symposium, Intellectual Property and Contract Law for the Information Age: The Impact of Article $2 B$ of the Uniform Commercial Code on the Future of Information Commerce, 87 CALIF. L. REV. 1 (1999). 
preemption could potentially radically alter UCITA's framework for information contracts and thus demands close attention.

\section{A. Symbiotic View}

Supporters of UCITA tend to view the relationship between contract and intellectual property law as "symbiotic" rather than competitive. ${ }^{81}$ Raymond Nimmer, Reporter for the Article 2B/UCITA project, views the relationship in the marketplace setting as one in which intellectual property law provides "default rules" for contractual dealings. ${ }^{82}$ Federal intellectual property laws function as default rules in the sense that the effect of the rule can be altered by contract within traditional contract law limits. $^{83}$

Fundamental to an understanding of the preemption debate is section 301(a) of the Copyright Act, which expressly preempts any "legal or equitable rights that are equivalent to any of the exclusive rights within the general scope of copyright." ${ }^{, 84}$ A right is "equivalent" if the mere act of reproduction, performance, distribution, or display infringes it. ${ }^{85}$

Rights created by licenses of copyrightable material, such as those covered by UCITA, are not always equivalent to the exclusive rights of copyright law. ${ }^{86}$ UCITA supporters suggest that license-created rights may be distinguished from copyright rights in two ways. First, if the right at issue is not infringed by mere reproduction, performance, distribution, or display-the actions protected against by the exclusive copyright rightsthen it is not equivalent. For example, in National Car Rental Systems, Inc. v. Computer Assoc. International, Inc., the court interpreted defendant's act of processing data for third parties as beyond the parameter of these rights, and thus the breach of contract action was not subject to pre-

81. Raymond T. Nimmer, Breaking Barriers: The Relations Between Contract and Intellectual Property Law, 13 BERKELEY TECH. L.J. 827, 827-29 (1998); see also generally Joel Rothstein Wolfson, Contract and Copyright Are Not at War: a Reply to "The Metamorphosis of Contract into Expand," 87 CALIF. L. REV. 79 (1999).

82. See Nimmer, supra note 81 , at $844-45$.

83. See id.

84. 17 U.S.C. $\$ 301$ (a) (1994).

85. See id. $\$ 106 ; 1$ Melville B. Nimmer \& DAvid NimmER, NimMER ON COPYRIGHT $\S 1.01[\mathrm{~B}]$ at $1-13$ (1999).

86. See National Car Rental Sys., Inc. v. Computer Assoc. Int'l., Inc., 991 F.2d 426, 432-33 (8th Cir. 1993) (holding that contractual restriction on processing of data for third parties constitutes an additional element distinguishing this cause of action from a copyright action); Taquino v. Teledyne Monarch Rubber, 893 F.2d 1488, 1501 (5th Cir. 1990) (holding that an action for breach of contract involves an element in addition to "mere reproduction," and hence the contract right is not equivalent to a copyright right). 
emption. ${ }^{87}$ Second, even if the right falls into the general category of copyright rights, state law is not preempted under section 301(a) if it requires an "extra element" to establish the cause of action. ${ }^{88}$ In contractual claims, the extra element may consist of proof of the contractual relationship, its terms, and the conduct that violates those terms as applicable to the particular parties. ${ }^{89}$ In other words, if the restriction would not exist absent the parties' agreement, then the contractual restriction constitutes an "extra element," and there is no preemption. ${ }^{90}$ From the symbiotic perspective, cases in which federal intellectual property law has been used to preempt state law can be distinguished on their lack of contract-based content. ${ }^{91}$

Furthermore, although one function of section 301(a) is to prevent states from giving special protection to works of authorship that Congress has decided should be in the public domain, federal intellectual property laws are not the only source of property rights. ${ }^{92}$ For example, privacy notions and criminal law create rights to prevent a party from breaking into one's office and stealing her database, even if the database is not copyrightable. ${ }^{93}$ In fact, trade secret law, a branch of state common law, can cover material that cannot be protected by copyright, such as a customer list of phone numbers. ${ }^{94}$

Another important distinction is the ubiquitous enforceability of copyright rights against all others in contrast to the targeted reach of licensed rights. Rights within the meaning of section 301(a) are rights established by law, and thus "a right against the world." 95 Private contracts, on the other hand, only affect the parties involved. Strangers are not bound by the specific license terms. ${ }^{96}$

87. See National Car Rental, 991 F.2d at 433.

88. See NIMMER, supra note $85, \S 1.01[\mathrm{~B}]$ at 1-13.

89. See Nimmer, supra note 81 , at 862 .

90. See National Car Rental, 991 F.2d at 433.

91. See Bonito Boats, Inc. v. Thunder Craft Boats, Inc., 489 U.S. 141 (1989) (invalidating state law giving property right to boat designers against third parties as preempted by federal patent law principles). Bonito Boats can be distinguished based on the lack of an underlying contract; that is, the statute created rights against all third parties from using design. But see Vault Corp. v. Quaid Software L.t., 847 F.2d 255, 268-70 (5th Cir. 1988) (preempting state statute that had permitted licensors to limit certain copyright privileges in shrinkwrap licenses).

92. See ProCD, Inc. v. Zeidenberg, 86 F.3d 1447, 1453 (7th Cir. 1996).

93. See Nimmer, supra note 81 , at 834 .

94. See ProCD, 86 F.3d at 1454.

95. Id.

96. See id. 
The symbiotic view maintains that private promises to pay for information may be enforced even though federal intellectual property laws (here, copyright law) do not extend protection over that material. ${ }^{97}$ If section 301(a) is meant to abolish consensual protection of any material within the "scope of copyright" but not actually protected by copyright law, then the Supreme Court's enforcement of trade secret agreements would be severely limited. After all, many trade secret contracts encompass noncopyrightable material, such as customer lists, but such contracts are clearly assumed (and desired) to be enforceable today. ${ }^{98}$

More generally, the Supreme Court has read preemption clauses to leave private contracts unaffected. In American Airlines, Inc. v. Wolens, ${ }^{99}$ the relevant federal statute preempted any state "law, rule, regulation, standard, or other provision" that "relat[es] to rates, routes, or services of any air carrier." ${ }^{100}$ However, the court held the statute should not be read so broadly as to preempt the private terms of air carrier contracts. Terms and conditions offered by contract reflect private ordering, essential to the efficient functioning of markets. ${ }^{101}$ Anti-preemptionists argue that the courts will likely show similar deference to licenses under UCITA.

\section{B. Preemptive View}

Critics of the ProCD decision, ${ }^{102}$ however, argue that some massmarket information licenses jeopardize the policy goals of copyright law by impeding the flow of information into the public domain, and more specifically, by limiting the "fair use"103 and "first sale"104 doctrines. ${ }^{105}$

97. See, e.g., Aronson v. Quick Point Pencil Co., 440 U.S. 257, 262-66 (1979) (upholding royalty agreement between patent applicant and company for the manufacture and sale of device even after patent for the device was denied); Kewanee Oil Co. v. Bicron Corp., 416 U.S. 470, $492-94$ (1974) (holding that agreements under state trade secret law were not preempted by patent law because the two different levels of protection could exist in harmony).

98. See ProCD, 86 F.3d at 1454.

99. 513 U.S. 219 (1995).

100. Id. at 229.

101. See id. at 228-32.

102. See ProCD, Inc. v. Zeidenberg, 86 F.3d 1447, 1449, 55 (7th Cir. 1996) (validating shrinkwrap license terms that restricted use of a non-copyrightable computer database of telephone directories).

103. See 17 U.S.C. $\$ 107$ (1994) ("[T]he fair use of a copyrighted work, including such use by reproduction in copies or phonorecords or by any other means specified by that section, for purposes such as criticism, comment, news reporting, teaching . . scholarship, or research, is not an infringement of copyright."). The fair use doctrine "permits [and requires] courts to avoid rigid application of the copyright statute when, on occasion, it would stifle the very creativity which that law is designed to foster." Campbell $\mathrm{v}$. 
Preemption may be necessary, they argue, to prevent such contracts that alter the copyright balance and to ensure that the objectives of Congress are met under the U.S. Constitution's Supremacy Clause. ${ }^{106}$

David Nimmer distinguishes ProCD from the underlying cases ${ }^{107}$ establishing the nonapplicability of the preemption doctrine to private contract terms on the basis that express copyright preemption under section 301 applies to contract claims that directly assert the reproduction right. ${ }^{108}$ The "extra element" test, favored by the anti-preemptionists, often yields results contrary to the intent of the copyright statute, mostly due to the flexibility a court has in finding the extra element needed for state law to survive preemption. ${ }^{109}$ More generally, critics of UCITA argue that it confers rights more akin to property than contract rights due to the marketwide restrictions imposed by mass-market shrinkwrap licensing. ${ }^{110}$ Unlike a typical two-party contract, UCITA licenses can operate to have the same scope and effect of state copyright legislation. ${ }^{111}$ Given the widespread impact of these mass-market limitations, preemption might be appropriate.

Broader conflict preemption ${ }^{112}$ principles provide another argument for preemption when licenses frustrate specific objectives of Congress

Acuff-Rose Music, Inc., 510 U.S. 569, 577 (1994) (alteration in original and citation omitted).

104. See 17 U.S.C. $\$ 109$ (a) (1994) ("[T]he owner of a particular copy or phonorecord lawfully made under this title ... is entitled, without the authority of the copyright owner, to sell or otherwise dispose of the possession of that particular copy or phonorecord.").

105. See, e.g., The Committee on Copyright and Literary Property of the Association of the Bar of the City of New York, Report on a Proposal of the National Conference of Commissioners on Uniform State Laws to Adopt a Uniform Proposed Computer Information Transactions Act at 16-21 (June 21, 1999), available at $\langle$ http://www.2Bguide.com/docs/Copy.Comm1.pdf) (PDF file) [hereinafter NYC Bar Report].

106. See U.S. CONST. art. VI, cl. 2 ("This Constitution, and the Laws of the United States, which shall be made in Pursuance thereof, and all Treaties made, or which shall be made, under the Authority of the United States, shall be the supreme Law of the Land."); David Nimmer et al., The Metamorphosis of Contract into Expand, 87 CALIF. L. REV. 19, 40-41 (1999).

107. See supra note 86.

108. See Nimmer et al., supra note 106, at 50.

109. See Patrick McNamara, Note, Copyright Preemption: Effecting the Analysis Prescribed by Section 301, 24 B.C. L. REV. 963, 984-985 (1983).

110. See NYC Bar Report, supra note 105, at 17-18.

111. See id. at 18.

112. "Conflict preemption" occurs "when compliance with both federal and state laws is a physical impossibility or where state law stands as an obstacle to the accomplishment and execution of Congress's full purposes and objectives." $l d$. at 4 . 
through such terms as "Feist-defeating" provisions ${ }^{113}$ and limitations on fair use and first sale rights. ${ }^{114}$ In particular, UCITA's default rules on the duration of contractual rights and restrictions could be preempted. ${ }^{115}$ UCITA provides that if a contract for software does not specify the duration of rights granted, those rights are "perpetual." lotte $v$. Thys $\mathrm{Co} .{ }^{117}$ forbidding the extension of the term of federal patent protection in a patent license, and P.C. Films Corp. v. MGM/UA Home Video Inc., ${ }^{118}$ questioning the validity of a license that extends rights beyond the copyright renewal period, support the supremacy of the intellectual property laws in this area. Preemptionists can point to Brulotte as clear precedent that private contracts governing intellectual property cannot interfere with specific congressional objectives. The UCITA rule may conflict not only with the above case law, but also more fundamentally with the constitutional requirement, enacted via copyright law, that such works (and their licensed rights) be protected for a limited term. ${ }^{119}$

\section{Which View is Right? Information Incentives vs. Public Domain Access}

Although both sides engage in a clever reading of the cases and doctrines, the determination of which viewpoint-symbiotic or preemptiveis correct reduces to an underlying tension between promoting the burgeoning information industry and defending the public domain as set by copyright law. After the Supreme Court's ruling in Feist Publications $v$. Rural Telephone Service, ${ }^{120}$ which denied copyright protection to com-

113. This reference is to protection, such as license in ProCD case, of material (i.e. telephone listing database) determined to be uncopyrightable in Feist Publications $v$. Rural Telephone Service, 499 U.S. 340 (1991).

114. See Nimmer et al., supra note 106, at 50-60. Several other potential conflicts exist between policies permitted under UCITA and those fixed by federal copyright laws. For example, the Copyright Act provides that any assignment or exclusive license of any copyright right is not valid without a writing signed on behalf of the owner. See NYC Bar Report, supra note 105, at 10-11 (citing 17 U.S.C. $§ 204$ (a)). UCITA, however, authorizes oral copyright transfers under certain conditions. See id. at 11 (citing UCITA $\S$ 201(f)). Another potential conflict exists between the statute of limitation under UCITA (four or five years) and the Copyright Act's three-year statute of limitations. See id. at 14.

115. See NYC Bar Report, supra note 105, at 13-14 (arguing that copyright law's limited term of protection is in tension with the longer duration of license restrictions permitted under UCITA).

116. See UCITA § 308(2) (Oct. 15, 1999 Draft).

117. 379 U.S. 29, 33-34 (1964).

118. 138 F.3d 453, 458 (2d Cir. 1998).

119. See U.S. ConST. art. I, § 8, cl. 8; 17 U.S.C. $\S \S ~ 203,302-304$ (1994) (limiting duration of copyright and licensed rights to the term of the copyright).

120. 499 U.S. 340 (1991). 
mercially valuable databases of information, the only way left for compilers to reap the benefit of assembling such information is through private agreements. Similarly, given the ease of copying and distributing software, software licensors may need contractual limitations on the first-sale doctrine to ensure viability. If these contracts were deemed unenforceable under section 301(a), the information industry might not be economically sustainable. Without adequate information incentives, the intellectual property goal of increasing the production and sharing of information with the public would ultimately suffer. ${ }^{121}$

While the policy aims of protecting socially desirable information services make practical sense, prudential arguments should take a back seat to Congress's balancing of the public domain as expressed through federal copyright law. Anti-preemptionists assert that the "extra element" test defeats section 301 preemption. However, under this test, no contractual variation of the exclusive rights conferred by copyright could be considered preempted, since the contract itself supposedly constitutes the necessary extra element. This would reduce the express preemption clause of section 301 to surplusage, a result certainly not intended by Congress. Furthermore, the precise issue here is not whether a private contract is subject to preemption in general, but rather whether a state law allowing certain contractual terms can be preempted. The Fifth Circuit directly addressed this question in Vault Corp. v. Quaid Software Ltd. ${ }^{122}$ In Vault, the court struck down a state statute validating shrinkwrap license terms that imposed perpetual copying restrictions as being in conflict with section 117 of the Copyright Act. ${ }^{123}$ Since the preempted statute governed state contract law, much like UCITA does, ${ }^{124}$ the Vault decision defies the antipreemptionists' contention that rights based on an underlying contract cannot be preempted.

Even if the "extra element" test could be applied here, constitutionallybased conflict preemption permits courts to transcend the limits of section 301 preemption and uphold congressional enactments of doctrines such as first sale and fair use. Further, contractual protection of databases under

121. See, e.g., Wolfson, supra note 81 , at $84-87$ (describing the growing value of noncopyrightable material in the U.S. economy and the potential loss of such useful information without adequate protection).

122. 847 F.2d 255 (5th Cir. 1988).

123. See id. at 270.

124. See id. at 268-70. But critics try to distinguish Vault because the court started with the presumption that the underlying contract was unenforceable absent the state statute, so no real contract existed. See Nimmer, supra note 81 , at 864 . However, nothing prevents a court from following the same process and reaching the same result under UCITA. 
UCITA would amount to state-law-sanctioned circumvention of Feist. Such an encroachment on the public domain as determined by Congress should not be tolerated under contract preemption principles.

Several federal doctrines other than preemption could also be invoked to invalidate contract terms relating to rights under copyright law. ${ }^{125} \mathrm{Al}-$ though a fuller discussion is beyond the scope of this comment, examples include First Amendment law, antitrust law, ${ }^{126}$ copyright misuse, ${ }^{127}$ and various other federal policy ${ }^{128}$ doctrines. ${ }^{129}$

\section{EFFECT ON UNIFORMITY}

As indicated by its name, UCITA's foremost goal is to create a uniform body of law to govern all computer information transactions irrespective of state boundaries. Given the inherently interstate nature of computer information transactions, variations in law from state to state impose especially heavy costs and uncertainty on such transactions. A consistent set of rules would substantially reduce uncertainty and transaction costs associated with the extra confusion, negotiation, and litigation that result from contracting under a conflicting set of laws. ${ }^{130}$

However, as UCITA stands now, the goal of uniformity is in serious jeopardy. From a substantive perspective, the possibility of federal preemption of select UCITA provisions ${ }^{131}$ could create significant gaps and

125. See Wolfson, supra note 81 , at 104.

126. See generally 2 EARL W. KinTNER, Federal ANTITRUST LAW $\S \S 10.19-10.38$ (1980) (discussing various theories that precluded refusals to bargain under $\S \S 1$ and 2 of the Sherman Act).

127. See Mark Lemley, Beyond Preemption: The Law and Policy of Intellectual Property Licensing, 87 CALIF. L. REV. 113, 151-58 (1999) (arguing that copyright misuse, analogous to patent misuse doctrine but distinct from antitrust law, cannot be waived by contract and may prove to be a better tool than preemption due to its fact-specific nature).

128. See id. at 158-63 (arguing that interpretation of contracts under federal law rather than state law for some intellectual property licenses would provide a second nonpreemption limit on UCITA's ability to change rules within the federal domain). One example is the application of the federal estoppel doctrine, which supercedes state law in determining when challenges of patent validity are permitted. See id. at 160-61.

129. The availability of these alternatives in itself, however, can be used as an argument in favor of rejecting the broad determination that all contract terms of a certain type are automatically preempted. See Wolfson, supra note 81, at 104.

130. See generally UCITA, Prefatory Note (July 1999 draft).

131. For a detailed discussion on which parts of UCITA are most susceptible to federal preemption, see supra Part III. 
render its content uncertain. ${ }^{132}$ In fact, UCITA acknowledges this danger by explicitly stating that any of its provisions are unenforceable to the extent they are preempted by federal law. ${ }^{133}$ On its face, UCITA takes a neutral stance to preemption questions based on the proposition that preemption is an issue to be resolved at the federal level and thus beyond UCITA's scope. ${ }^{134}$ But this neutral stance can misleadingly induce merchants and consumers to rely on state rules that do not, in actuality, apply to their transactions. ${ }^{135}$ Thus, regardless of one's view of their merit, the preemption issues should be directly addressed and clarified before UCITA's passage.

In addition to the uncertainty surrounding federal preemption, UCITA creates the potential for nonuniformity by deferring certain questions to other individual bodies of state law such as consumer protection laws. ${ }^{136}$ However, as Article 2's history reveals, "federal and non-uniform state enactments in the consumer protection area effectively either preempted or modified parts of Article 2." 137 UCITA has the opportunity to directly incorporate consumer protections into its provisions, thereby avoiding the inconsistent, state-by-state changes introduced by the state law preemption that afflicted Article 2. ${ }^{138}$ Introducing stronger consumer protections into UCITA now would ensure greater uniformity in the long run. ${ }^{139}$

Uniformity will also be inhibited from a procedural standpoint. Localized interests in each state will seek to influence the legislative process,

132. Though beyond the scope of this Note, another substantive aspect of UCITA that will affect uniformity on a larger scale is its consistency with international regulations of computer information transactions. See O'Rourke, supra note 52, at 650-51, 65658 (1999) (comparing the approach of the European Union on the relationship between contracting and intellectual property; urging international discussion to reconcile conflicting provisions).

133. See UCITA § 105(a) (Oct. 15, 1999 Draft).

134. See id. $\S 105$, Official Comments $1,2$.

135. See NYC Bar Report, supra note 105, at 6-7.

136. See UCITA $\S 105$ (c) (Oct. 15, 1999 Draft) ("[I]f this [Act] conflicts with a consumer protection statute [or administrative rule], the conflicting statute [or rule] governs."); see also id. § 105, Official Comment 4.

137. O'Rourke, supra note 52, at 653 .

138. See id.

139. See id. One hypothetical scenario is the potential expansion of state product liability law to fill the void left by UCITA's inadequate protection of software licensees' interests. See Peter A. Alces, W(h)ither Warranty: The B(l)oom of Products Liability Theory in Cases of Deficient Software Design, 87 CALIF. L. REV. 269, 298-99 (1999). However, if UCITA affords satisfactory consumer warranty protections, such an outcome could be avoided. 
lobbying for changes that push UCITA in their favor. ${ }^{140}$ Depending on the eventual compromises reached in each state, these resulting variations could lead to divergent statutes. ${ }^{141}$ Even if UCITA escapes the local legislative process unscathed, judicial interpretation of the statute by fifty separate state court systems will lead to differences in how the law is applied. ${ }^{142}$ Specifically, the state courts' varying approaches to preemption questions as well as their application of vague UCITA standards such as "fundamental public policy"143. will result in different interpretations of the same statutory provisions. ${ }^{144}$ A much larger impediment to uniformity will present itself if only a handful of states actually pass UCITA. Given the controversy surrounding UCITA thus far, including loss of UCC status and objections by twenty-four state attorneys general, ${ }^{145}$ the likelihood of widespread passage is low. ${ }^{146}$

Finally, a premature codification of UCITA may do more harm than good. ${ }^{147}$ Due to the quickly evolving nature of the incipient computer information industry, business practices are still in a state of flux. The drafters' statement that UCITA is "accurate and not original" is difficult to digest given this rapid change. ${ }^{148} \mathrm{~A}$ few years' time translates into a generation for computer technology; therefore, waiting a short period would allow emerging business models to mature and allow us to assess how well the Uniform Electronic Transaction $\mathrm{Act}^{149}$ and current laws resolve issues

140. See NYC Bar Report, supra note 105, at 15.

141. See id.

142. See id.

143. UCITA $\$ 105$ (b) (Oct. 15, 1999 Draft).

144. See O'Rourke, supra note 52, at 649-50 (describing this result as the flexibility versus uniformity trade-off).

145. See supra note 15 (stating opposition of 24 state attorneys general).

146. Professor Mark Lemley expects that UCITA will only pass in a few states, such as Microsoft's home state of Washington. See Brenda Sandburg, UCC2B is Dead-Long Live UCITA (May 27, 1999) (http://www.callaw.com/stories/edt0527.html〉. As a result, there may actually be a reduction in uniformity with different states having different software licensing laws. On the other hand, NCCUSL's Carlyle Ring believes "there will be a significant number of states looking for a thought-out statute," and thus they will adopt UCITA or use it as a template for their own legislation. See id.

147. See generally Jean Braucher, Why UCITA, Like UCC Article 2B, Is Premature and Unsound (visited Sept. 6, 1999) 〈http://www.2Bguide.com/docs/0499jb.html〉.

148. See id.

149. The Uniform Electronic Transaction Act (UETA) was aiso passed by NCCUSL in July 1999. See Carol A. Kunze, The ETA Forum (last modified July 29, 1999) $\langle$ http://www.webcom.com/legaled/ETAForum〉. UETA has the limited objective of facilitating electronic commerce compared to the more extensive reach of UCITA over all aspects of computer information contracts. Many have praised its less drastic means and goals. See, e.g., Cem Kaner, E-Commerce Provisions in the UCITA and UETA (visited 
of concern. ${ }^{150}$ If a few states enact UCITA, however, balanced legislation will be much harder to pass in the near future since entrenched licensor interests will not be willing to compromise their favorable status. ${ }^{151}$

\section{CONCLUSION}

Given UCITA's potentially negative impact on consumers, as well as upon the larger goals of uniformity and certainty, UCITA should be reconsidered and restructured. UCITA's scope, broadened even further by the power of the opt-in provision, engulfs too many types of mass-market information transactions without providing adequate requirements for meaningful assent and warranty protection. Furthermore, federal preemption places the coherency of UCITA's entire regime in doubt, leaving the possibility of a fragmented contract framework that still varies from state to state. Unless these concerns are carefully addressed, we may be stuck with an unworkable piece of legislation guiding a budding and valuable industry in the wrong direction.

Sept. 6, 1999) 〈http://www.badsoftware.com/uetaanducitauccbull.htm〉 (briefly discussed supra note 79).

150. See Braucher, supra note 147.

151. See id. 
